\title{
Plasma Ceruloplasmin and Fibrinogen during Enzyme Therapy of Mastitis in Dairy Cows
}

\author{
J. BAKES̆ ${ }^{1}$, J. ILLEK ${ }^{2}$ \\ ${ }^{1}$ Hospital Pharmacy (Podřipská Hospital and Health Centre), Roudnice nad Labem \\ ${ }^{2}$ Clinic of Ruminant Diseases, Faculty of Veterinary Medicine, \\ University of Veterinary and Pharmaceutical Sciences Brno
}

Received September 23, 2005

Accepted November 16, 2005

\begin{abstract}
Bakeš J, J. Illek: Plasma Ceruloplasmin and Fibrinogen during Enzyme Therapy of Mastitis in Dairy Cows. Acta Vet. Brno, 2006, 75: 241-246.

The aim of this study was to demonstrate the benefits of topical administration of proteolytic enzymes used in the symptomatic mastitis therapy. Eleven lactating cows with clinical signs of mastitis in one udder quarter at least were divided into two groups. Group A was given an antibiotic alone - cefotaxime (250 mg, intramammary administration, 6 doses in total). Group B was given a lower dose of the same antibiotic (cefotaxime, $100 \mathrm{mg}$, intramammary administration, 5 doses in total) and a blend of enzymes in one drug form, i.e. both the dose and total number of administrations were lower in this group. Before and after the therapy, milk samples were collected and subjected to microbiological examination, and blood samples were withdrawn to determine fibrinogen and ceruloplasmin as acute phase proteins. Before the beginning of the therapy, common mastitis pathogens were detected in milk of both groups; after the end of the therapy, the test results were negative. Mean plasma concentrations of fibrinogen in Group A increased significantly from $6.0 \pm 1.4$ to $7.4 \pm 1.1 \mathrm{~g} \cdot \mathrm{l}^{-1}$, in Group B a non-significant decrease was observed, from $6.5 \pm 0.86 \mathrm{~g} \cdot 1^{-1}$ to $6.4 \pm 0.9 \mathrm{~g} \cdot \mathrm{l}^{-1}$. However, differences between the groups were significant $(p<0.05)$. In Group A, mean plasma ceruloplasmin concentration increased significantly from $0.9 \pm 0.2$ to $1.3 \pm 0.18 \mu \mathrm{mol} \cdot \mathrm{l}^{-1}$, and in Group B it decreased non-significantly from $0.9 \pm 0.36$ to $1.1 \pm 0.26 \mu \mathrm{mol} \cdot 1^{-1}$, and the difference between the groups was non-significant. In the present study, a favourable effect of repeated topical application of a mixture of proteolytic enzymes was demonstrated. The enzyme therapy resulted in a decreased therapeutic dose of the antibiotic, and suppressed an increase in the levels of inflammation markers under investigation.
\end{abstract}

Bromelain, cefotaxime, chymotrypsin, papain

Particularly during acute mastitis, the mammary gland shows typical signs of inflammatory process. In order to provide the shortest and most effective therapy of acute mastitis, it is necessary to support causal therapy, focused on the causative agent (antiinfectives) using symptomatic therapy to suppress the inflammation (antiflogistics). In practice, glucocorticoids have been widely used, non-steroid antiflogistics (NAF) and enzymes have been used less frequently. Many studies demonstrated that the effects of enzymes are comparable with those of NAF (Salamberidze et al. 2002). The systemic effect is the most pronounced in glucocorticoids, even when it comes to undesirable effects. Unlike enzymes, glucocorticoides show an anti-inflammatory effect accompanied by immunosuppression. Positively adjuvant effects of enzyme therapy include the potentiation of antibiotic effect at a site of inflammation, an increase in the acute cell response and an anti-oedema effect of trypsin, chymotrypsin and bromelain, and an oedema-protective effect of papain (Kass eroller and Wenning 2003). Doses of antibiotics, when combined with the enzyme therapy, can be decreased to a half of the monotherapeutic ones (Suchich et al. 1997), and at the same time the regression of clinical disease signs is accelerated (Tinozzi and Venegoni 1978; Luerti and Vignali 1978; Neubauer 1961). Proteases

Address for correspondence:

PharmDr. Josef Bakeš

Chief pharmacist, Hospital Pharmacy

Podřipská nemocnice s poliklinikou Roudnice n.L., s.r.o.

Alej 17. listopadu 1101, Czech Republic

Phone: +420 606603578

E-mail: lekarnik@seznam.cz

http://www.vfu.cz/acta-vet/actavet.htm 
change the spectrum of adhesive molecules in the cell membrane (W ald et al. 2001), which favourably influences the production of different types of cytokines. Proteases increase the clearance of anti-inflammatory cytokines (Des s er et al. 1999; Des ser et al. 2001; Xiang et al. 2001), as well as plasminogen concentration in blood. They also decrease fibrin formation and dissolve the existing thrombi. Decreased thrombocyte aggregation helps to maintain correct microcirculation (Nouza et al. 1999).

The aim of the present study was to demonstrate the beneficial effects of topical administration of proteolytic enzymes used as symptomatic therapy of mastitis with decreased total antibiotic doses. For the evaluation, we have chosen the results of development of ceruloplasmin and fibrinogen dynamics and microbiological examination of collected milk and blood plasma samples.

\section{Materials and Methods}

A field part of the study was performed on the farm Těsany u Brna, owned by the company AGRO MONET a.s. Moutnice. The study included 11 lactating cows that met the following criteria: clinical signs of inflammation present in at least one quarter, 4-12 years of age, an apparent and unplanned decrease in the volume of milk produced, positive results of barn mastitis test, changes in milk quality. Right after the allocation to the study, each lactating cow was placed in quarantine. Collected milk was discharged until the end of withdrawal period of a drug used. Lactating cows were randomly allocated to two groups. Group A received only a broad-spectrum ß-lactam antibiotic, cephalosporin of $3^{\text {rd }}$ generation - cefotaxime at a single dose of $250 \mathrm{mg}$, made by galenic modification of Taxcef inj. $1 \times 1 \mathrm{~g}$ (Ranxbay, UK) in the sterile suspension-ointment basis. The ointment was applied twice a day for 3 days intramammarily, only to inflamed quarters.

Group B received the same antibiotic (cefotaxime $100 \mathrm{mg}$ ) and a mixture of enzymes in one drug form. The enzyme mixture was made from 3 coated tablets of the registered enzyme preparation Wobenzym drg. (Mucos, Germany), modified galenically. Proportions of proteolytic activities were as follows: $46.15 \%$ papain, $18.46 \%$ trypsin, $0.77 \%$ chymotrypsin a $34.61 \%$ bromelain. The preparation was applied only into inflamed quarters. The following protocol was used: first and second day - one dose BID, third day: one dose SID. Both the dose and number of administrations were lower, as compared with Group A. In both groups, the drugs were administered in the form of intramammary sterile suspension ointment at a dose of $10 \mathrm{~cm}^{3}$, by a disposable sterile injector. A conic tip of the injector was carefully inserted into the teat of an affected quarter. By pressing the injector, all its contents were squeezed into the quarter. This was always done after thorough milking and teat tip disinfection. The preparation was kept refrigerated at $2-8^{\circ} \mathrm{C}$. It was taken out of the refrigerator about 15 min before the administration. Before and $12-24$ hours after the therapy, milk and blood samples were collected. Milk samples were obtained by squirting the middle flow of milk from all the productive quarters to sterile glass test tubes. The samples were examined at the microbiological laboratory of the State Veterinary Institute Brno for the presence of Streptococcus agalactiae, Str. dysgalactiae, Str. uberis, Staphylococcus aureus, E. coli and Klebsiella. Blood was withdrawn from the tail vein into plastic vacuum sterile tubes and was used to determine fibrinogen and ceruloplasmin as acute phase proteins. Fibrinogen was measured by the turbidimetric analysis, using the set FIBRINOGEN Boehringer Mannheim. Ceruloplasmin levels in the serum were measured (Henry et al. 1974) using the biochemical analyser COBAS MIRA S, at the laboratory of clinical biochemistry at the Clinic of Ruminant Diseases of the Faculty of Veterinary Medicine, University of Veterinary and Pharmaceutical Sciences Brno. For the statistical analysis of levels of both acute phase proteins, F-test and paired and non-paired $t$-tests were used. The difference was regarded as statistically significant at $p<0.05$.

\section{Results}

In Group A, 18 quarters were affected in total. Mean total dose per one quarter was at least $1400 \mathrm{mg}$ cefotaxime. In Group B, 18 quarters were affected in total. Mean total dose per one quarter was $500 \mathrm{mg}$ cefotaxime and $1870 \mathrm{mg}$ total enzyme. Results of microbiological examination are listed in Table 1. Before the therapy the respective pathogenes were found in milk samples from all the cows monitored, but with Str. agalactiae prevailing (7 samples); bacteriological examination of the samples obtained 24 hours after the therapy showed negative results (Table 1). In Group A, mean plasma concentrations of fibrinogen were $6 \pm 1.4 \mathrm{~g} \cdot \mathrm{l}^{-1}$ before the therapy and $7.4 \pm 1.1 \cdot \mathrm{g}^{-1}$ after the therapy. In Group B, mean initial and final plasma fibrinogen concentrations were $6.5 \pm 0.86 \cdot \mathrm{g}^{-1}$ and $6.4 \pm 0.9 \cdot \mathrm{g}^{-1}$, respectively. Fibrinogen levels on the initial and final days 
Table 1. Initial and final results of bacteriological examination in individual cows

\begin{tabular}{|c|l|c|c|c|c|}
\hline \multicolumn{3}{|c|}{$\begin{array}{r}\text { Group A } \\
\text { Bacteriological finding }\end{array}$} & \multicolumn{3}{c|}{$\begin{array}{c}\text { Group B } \\
\text { Bacteriological finding }\end{array}$} \\
\hline Cow No. & Before therapy & After therapy & Cow no. & Before therapy & After therapy \\
\hline 1. & Str. dysgalactiae & 0 & 7. & Str. agalactiae & 0 \\
\hline 2. & Str. agalactiae & 0 & 8. & Str. agalactiae & 0 \\
\hline 3. & Str. agalactiae & 0 & 9. & Enterococcus sp., E. coli & 0 \\
\hline 4. & $\begin{array}{l}\text { Str. agalactiae } \\
\text { Enterococcus } \text { sp. }\end{array}$ & 0 & 10. & E. coli & 0 \\
\hline 5. & Str. agalactiae & 0 & 11. & Enterococcus sp. & 0 \\
\hline 6. & Str. agalactiae & 0 & & & \\
\hline
\end{tabular}

Table 2a. Initial and final values of fibrinogen and evaluation by paired $t$ - test

\begin{tabular}{|l|c|c|l|l|c|}
\hline \multicolumn{2}{|c|}{$\begin{array}{c}\text { Group A } \\
\text { (cefotaxime) }\end{array}$} & \multicolumn{3}{c|}{$\begin{array}{c}\text { Group B } \\
\text { (cefotaxime + mixture of enzymes) }\end{array}$} \\
\hline \multicolumn{3}{|c|}{ fibrinogen $\left(\mathrm{g} \cdot \mathrm{l}^{-1}\right)$} \\
\hline Cow No. & Before therapy & $\begin{array}{c}\text { After therapy } \\
(4 \text { th day) }\end{array}$ & Cow no. & Before therapy & $\begin{array}{c}\text { After therapy } \\
\text { (4th day) }\end{array}$ \\
\hline 1 & 7.2 & 7.6 & 7 & 7.8 & 7.2 \\
\hline 2 & 4.6 & 6.2 & 8 & 5.6 & 5 \\
\hline 3 & 8.2 & 9.5 & 9 & 5.8 & 6.2 \\
\hline 4 & 6.3 & 7.5 & 10 & 6.2 & 5.9 \\
\hline 5 & 4.2 & 6.6 & 11 & 7.3 & 7.5 \\
\hline 6 & 5.2 & 6.8 & & & 6.2 \\
\hline Median & 5.75 & 7.15 & Median & 6.2 & 6.36 \\
\hline Mean & 5.95 & 7.37 & Mean & 6.54 & 0.9 \\
\hline S.D. & 1.43 & 1.07 & S.D. & 0.86 & 0.780568 \\
\hline T-test & 0.003143 & & T-test & & \\
\hline
\end{tabular}

Table 2b. Comparison of percentage changes in fibrinogen levels between the groups by non-paired $t$-test

\begin{tabular}{|l|c|}
\hline & Group A vs. B \\
\hline F-test & 0.105584 \\
\hline$t$-test & 0.0079 \\
\hline
\end{tabular}

within one group, compared by the paired $t$-test (Table 2a), were significant only in Group A where an increase in fibrinogen levels by $27 \%$ on average on the 4 th day, as compared with the initial values, was found. Changes in Group B were non-significant, although most cows showed an apparent decrease as compared with the initial values. When comparing percentage changes of the indicators under study between the groups (Table 2b), Group B showed a marked decrease compared to Group A. In Group A, mean ceruloplasmin concentrations were $0.9 \pm 0.2 \mu \mathrm{mol} \cdot l^{-1}$ before the therapy, and $1.3 \pm 0.18 \mu \mathrm{mol} \cdot 1^{-1}$ thereafter. In Group B, mean ceruloplasmin concentrations were $0.9 \pm 0.36 \mu \mathrm{mol} \cdot \mathrm{l}^{-1}$ before the therapy and $1.1 \pm 0.26 \mu \mathrm{mol} \cdot 1^{-1}$ thereafter. Ceruloplasmin concentrations $\left(\mu \mathrm{mol} \cdot 1^{-1}\right)$ were compared between the first and last day within the groups using the paired $t$-test (Table $3 \mathrm{a}$ ). Statistical significance was achieved only in Group A where ceruloplasmin concentrations increased by $49 \%$ on average compared to initial values. Changes observed in Group B were not significant, although in all cows an increase from the initial values was obvious. No statistical significance was found in percentage changes of the variable under study between the groups (Table 3b). 
Table 3a. Initial and final values of ceruloplasmin and evaluation by paired $t$-test

\begin{tabular}{|c|c|c|c|c|c|}
\hline \multicolumn{3}{|c|}{$\begin{array}{c}\text { Group A } \\
\text { (cefotaxime) }\end{array}$} & \multicolumn{3}{|c|}{$\begin{array}{c}\text { Group B } \\
\text { (cefotaxime }+ \text { mixture of enzymes) }\end{array}$} \\
\hline \multicolumn{3}{|c|}{ ceruloplasmin $\left(\mu \mathrm{mol} \cdot 1^{-1}\right)$} & \multicolumn{3}{|c|}{ ceruloplasmin $\left(\mu \mathrm{mol} \cdot 1^{-1}\right)$} \\
\hline Cow No. & Before therapy & $\begin{array}{l}\text { After therapy } \\
\text { (4th day) }\end{array}$ & Cow no. & Before therapy & $\begin{array}{c}\text { After therapy } \\
\text { (4th day) }\end{array}$ \\
\hline 1 & 0.89 & 1 & 7 & 1.16 & 1.26 \\
\hline 2 & 1.09 & 1.39 & 8 & 0.52 & 0.78 \\
\hline 3 & 0.95 & 1.5 & 9 & 1.38 & 1.4 \\
\hline 4 & 1.07 & 1.45 & 10 & 0.67 & 1.16 \\
\hline 5 & 0.5 & 1.16 & 11 & 0.63 & 0.77 \\
\hline 6 & 0.87 & 1.13 & & & \\
\hline Median & 0.92 & 1.275 & Median & 0.67 & 1.16 \\
\hline Mean & 0.9 & 1.27 & Mean & 0.87 & 1.07 \\
\hline S.D. & 0.2 & 0.18 & S.D. & 0.36 & 0.26 \\
\hline$t$-test & 0.005827 & & $t$-test & 0.068889 & \\
\hline
\end{tabular}

Table 3b. Comparison of percentage changes in ceruloplasmin concentrations between the groups by non-paired $t$-test

\begin{tabular}{|l|c|}
\hline & Group A vs. B \\
\hline F-test & 0.498258 \\
\hline$t$-test & 0.434889 \\
\hline
\end{tabular}

\section{Discussion}

In the field trial when enzymes were used as a support in the mastitis therapy, a positive effect of repeated topical application of a mixture of proteolytic enzymes was demonstrated. The enzyme therapy allowed for a decrease in the dose of the antibiotic, and suppressed an increase in ceruloplasmin and fibrinogen concentrations as inflammation markers, suggesting a systemic effect of the topical administration. Group A cows were submitted to a conventional antibiotic therapy consisting in cefotaxime administration at a dose of 500 mg per an affected quarter per day. Group B was treated with both proteolytic enzymes and cefotaxime at a lower dose. Our expectation of benefits of the combined therapy was based on results of previously published studies that reported the ability of proteolytic enzymes (bromelain) to increase the concentration of antibiotics at a site of action (Luerti and Vignali 1978, Tinozzi and Venegoni 1978, Neubauer 1961). The mode of action has not been elucidated yet. A theory has been suggested on activation of protease-activated receptors (Olejar and Nouza 1998). Some in vitro studies based on a proof of cytotoxic activity of proteases led to conclusion that the presence of proteases caused a seven-fold increase in macrophage activity and a thirteen-fold increase in natural killer (NK) cell activity, only after 10 minutes of action (Desser et al. 1993). We assume that this might lead to higher concentrations of antibiotics at a site of application because of a higher activity of macrophages that phagocytize some antibiotics and incorporate them in the site of inflammation. Another suggested way of affecting the availability of antibiotics in the presence of proteolytic enzymes is the effect of enzymes on physical and chemical properties of plasma proteins that bind many antibiotics rendering them less available under normal circumstances. Lower doses of antibiotics imply a shorter withdrawal period for milk and financial savings. To evaluate the intensity of inflammation, the acute phase proteins, potential mastitis markers, fibrinogen and ceruloplasmin were monitored (Kovac et al. 2005).

Fibrinogen is the coagulation factor I, acute phase protein, and is produced more rapidly than degraded during the inflammation. Another important function of fibrinogen is the 
formation of fibrin matrix that enables the movement of fibroblasts and other cells and stimulates their production during the healing of damaged tissue ad secundam. Its biological half-time is 2.4 - 4.2 days (Masopust 1998). Unlike Group A in which a significant increase of fibrinogen concentration was observed, Group B (subjected to the enzyme therapy) showed a decrease, although a non-significant one. This might have been a response to direct or indirect anti-inflammatory effect of enzyme therapy, and would have corresponded with previously published results that attributed the enzyme therapy antioedema, fibrinolytic, anti-aggregation and therefore analgesic effects on the tissue affected with an inflammatory process (Kasseroler and Wenning 2003, Guggenbichler 1988). It is also possible that the suppression of increase of fibrinogen concentration is due to a direct fibrinolytic ability of some proteolytic enzymes (Nouza et al. 1999).

Ceruloplasmin is an inflammation marker, too, and it is degraded more rapidly than it is produced during the inflammation. The half-time of ceruloplasmin is 2-3 days (Masopust 1998). Therefore its decrease, even in case a therapeutic used exerts an anti-inflammatory effect, is delayed. In Group A we found a significant increase as compared to the initial values. No significant differences were found in Group B. In spite of that, in both groups the final values were higher (by $42 \%$ in Group A, by $23 \%$ in Group B) than the initial values. We assume that in Group A, the drug used affected directly the infectious agent, without an ability to directly influence the signs of inflammation which under normal circumstances diminish gradually, only during the healing process. By the moment of breakpoint in the process of damage and repair there is a limited persisting growth of marker values. Apparently, in Group B, the process of persisting growth was indirectly hindered by antiinflammatory effects of enzyme therapy. A significant effect on levels of acute phase proteins under study suggests a systemic effect of the proteolytic enzyme blend administered intramammarily.

In conclusion, it can be summarized that macromolecular substances of proteolytic enzyme nature, applied topically, exert a systemic effect, and a therapeutical approach combining enzymes and antibiotics not only enables to decrease doses of antibiotics, providing the same efficacy as the antibiotic monotherapy, but also may contribute to a reduction in the inflammation intensity.

We assume that the administration of antimicrobials along with selected proteases (bromelain, chymotrypsin) requires further investigations. This may help us find the most suitable therapy for infectious inflammations and related risks.

\section{Plazmatický ceruloplasmin a fibrinogen v průběhu enzymoterapie mastitid u dojnic}

Cílem studie bylo ověřit prospěšnost topického podání proteolytických enzymů jako symptomatické léčby mastitid. 11 dojnic v laktaci s klinicky manifestovaným zánětem minimálně jedné čtvrti vemene bylo rozděleno do dvou skupin. Skupině A bylo podáváno samostatné antibiotikum, cefotaxim (250 mg intramamárně, celkem 6 dávek). Skupině B byla aplikována nižší dávka téhož antibiotika (cefotaxim 100 mg intramamárně, celkem 5 dávek) a směs enzymů v jedné lékové formě. Oproti skupině A tak byla snížena jak dávka, tak celkový počet aplikací. Před zahájením a po ukončení terapie byly odebrány vzorky mléka k mikrobiologickému vyšetření a vzorky krve ke stanovení fibrinogenu a ceruloplasminu jako proteinů akutní fáze. V mléce obou skupin dojnic byly před započetím terapie prokázány běžné mastopatogeny, po léčbě byl bakteriologický nález negativní. Průměrná plazmatická koncentrace fibrinogenu u skupiny A signifikantně stoupla z $6 \pm 1.4$ na $7.4 \pm 1.1 \mathrm{~g} \cdot \mathrm{l}^{-1}$, u skupiny B nevýznamně poklesla z $6.5 \pm 0.86 \mathrm{~g} \cdot \mathrm{l}^{-1}$ na $6.4 \pm 0.9 \mathrm{~g} \cdot \mathrm{l}^{-1}$, rozdíl mezi skupinami byl významný $(p<0,05)$. Průměrná plazmatická koncentrace ceruloplazminu se zvýšila u skupiny A statisticky signifikantně z $0.9 \pm 0.2$ na 
$1.3 \pm 0.18 \mu \mathrm{mol} / \cdot \mathrm{I}^{-1}$ a u skupiny B nesignifikantně z $0.9 \pm 0.36$ na $1.1 \pm 0.26 \mu \mathrm{mol} \cdot \mathrm{l}^{-1} 1$, rozdíl mezi skupinami nebyl významný. Prokázali jsme pozitivní vliv opakované lokální aplikace směsi proteolytických enzymů. Enzymoterapie snížila terapeutické dávky antibiotika a potlačila vzestup sledovaných indikátorů zánětu.

\section{Acknowledgements}

The study was carried out within the research project NAZV QD 0176.

\section{References}

DESSER L, HERBACEK I, ZAVADOVA E, MOHRT 1999: Polyenzyme preparations interrupt the autocrine loop of TGF-beta production in melanoma cells by conversing alpha2Macroglobulin (a2M) into the fast-form which binds TGF-beta irreversible. Eur J Cancer 35: 375 p.

DESSER L, HOLOMANOVA D, ZAVADOVA E, PAVELKA K, MOHR T, HERBACEK I 2001: Oral therapy with proteolytic enzymes decreases excessive TGF-beta levels in human blood. Cancer Chemoth Pharm 47: $10-15$

DESSER L, REHBERGER A, KOKRON E, PAUKOVITS W 1993: Cytokine synthesis in human peripheral blood mononuclear cells after oral administration of polyenzyme preparations. Oncology 50: 403-407

HENRY R, CANNON D, WINKELMAN J 1974: Clinical Chemistry, Principles and Technics. Harper \& Row, New York,

KASSEROLLER R, WENNING H 2003: Efficacy and tolerability of proteolytic enzymes as an anti-inflammatory agent in lymphoedema after axillary dissection due to mammary cancer. Eur J Lymphol 10: 8-26

KOVAC G, VARGOVA M, POPELKOVA M, NOVOTNY J 2005: Acute Phase Proteins in Cattle. Achievements and Prospects of Ruminants Medicine. Pulawy, pp. 48-53

LUERTI M, VIGNALI M 1978: Influence of bromelain on penetration of antibiotics in uterus, salpinx and ovary. Drugs Exp Clin Res 4: 45-48

MASOPUST J 1998: Klinická biochemie: požadování a hodnocení biochemických vyšetření. II. část. Karolinum, Praha, $345 \mathrm{p}$.

NEUBAUER R 1961: A plant protease for potentiation of and possible replacement of antibiotics. Exp Med Surg 19: $143-160$

NOUZA K, OLEJAR T, NOUZA M 1999: Proteázy v regulaci a modulaci imunity. Klinická imunologia 3: 27-28

OLEJAR T, NOUZA K 1998: Trombin a trypsin regulují buněčnou odpověd aktivací specifických receptorů. Zpravodaj klinické farmakologie a farmacie 4: 19-22

SALAMBERIDZE L, KARTVELISHVILI, E, LORTKIPANIDZE M 2002: Effect of current administration of Taureodon and Wobenzym in Rheumatoid Arthritis. Int J Immunorehab 1: 110-111

SUCHICH G, LOGINOVA N, FAIZULLIN L, ZDANOV A, MALININA E, BOZEDOMOV V 1997: The use of Wobenzym to facilitate interferon synthesis in the treatment of chronic urogenital chlamydiosis. International Journal on Immunotherapy 13: 131-133

TINOZZI S, VENEGONI A 1978: Effect of bromelain on serum and tissue levels of amoxicillin. Drugs Exp Clin Res 4: 39-44

WALD M, OLEJAR T, SEBKOVA V, ZADINOVA M, BOUBELIK M, POUCKOVA P 2001: Mixture of trypsin, chymotrypsin and papain reduces formation of metastases and extends survival time of C57B16 mice with syngeneic melanoma B16. Cancer Chemother Pharmacol 47 Suppl: S16-S22

XIANG G, SCHINZEL R, SIMM A, MUNCH G, SEBEKOVA K, KASPER M, NIWA T, SCHMITZ C, HEIDLAND A 2001: Advanced glycation end products (AGEs)-induced expression of TGF-beta 1 is suppressed by a protease in the tubule cell line LLC-PK1. Nephrol Dial Transplant 16: 1562-1569 